Agrovoc descriptors: brassica napus, rapeseed, oil crops, crop yield, varieties, genotypes, wild plants, crops, cross pollination, reproduction, fertilization, sexual reproduction, gene transfer, purity, quality

Agris category code: F30, F01

\title{
Cultivation, varietal structure and possibilities for cross-pollination of Brassica napus L. in Slovenia
}

\author{
Barbara PIPAN ${ }^{1}$, Jelka ŠUŠTAR-VOZLIČ ${ }^{2}$, Vladimir MEGLIČ ${ }^{3}$
}

Received: June 7, 2011; accepted: September 14, 2011.

Prispelo 7 junija 2011; sprejeto: 14 septembra 2011.

\begin{abstract}
Oilseed rape, Brassica napus L., is one of the most important oil plants of the moderate climatic zone and a typical industrial plant. In the past, dynamics of oilseed rape production in Slovenia was reflected in flexible agricultural market situation because of introduction of new crops into rotation and due to financial supports from European Union. In 2010, it was cultivated on 5351ha, accounting for about $1.1 \%$ of the total production areas in Slovenia. It is mainly grown in the eastern part of Slovenia (Pomurje, Podravje) and in the Spodnje-Posavska region. From 1984 until 2010, 58 different genotypes of oilseed and fodder rape were grown in Slovenia, of which a total of 28 were registered in the National List of Varieties in each year. Average yield of oilseed rape was ranged between 1.8 and 2.9 t/ha. Under Slovenian fragmented property structure the cross-pollination between $B$. napus and volunteer or feral populations (within and outside the production area) can occur. In addition to that, the presence of some sexually compatible relatives which have a high affinity to cross-pollination with $B$. napus are found ( $B$. rapa, B. oleracea, B. nigra, Hirchfeldia incana, Raphanus raphanistrum, Sinapis arvensis, Diplotaxis erucoides, $D$. tenuifolia, D. muralis, S. alba, R. sativus and Rapistrum rugosum). Uncontrolled gene flow between different forms of $B$. napus or sexually compatible wild relatives in the case of coexistence of different production systems has a direct impact on the varietal purity of seeds and on crop quality.
\end{abstract}

Key words: Brassica napus L., oilseed rape, field production, varietal structure, wild relatives, volunteers, feral populations, gene flow

\section{IZVLEČEK}

\author{
PRIDELAVA, SORTNA STUKTURA IN \\ OPRAŠEVALNE SPOSOBNOSTI VRSTE Brassica napus \\ L. V SLOVENIJI
}

Oljna ogrščica, Brassica napus L., je najpomembnejša oljnica zmernega klimatskega pasu in tipična industrijska rastlina. V Sloveniji se je $\mathrm{v}$ preteklosti obseg njene pridelave zelo spreminjal zaradi prilagajanja razmeram na trgu, uvajanja novih poljščin $\mathrm{v}$ kolobar in zaradi neposrednih plačil s strani Evropske unije. V letu 2010 se je pridelovala na 5351ha, kar predstavlja okrog $1,1 \%$ vseh pridelovalnih površin. Največ se je pridela v vzhodni Sloveniji, in sicer v Pomurski, Podravski in Spodnje-posavski regiji. Od leta 1984 do 2010 se je na območju Slovenije pridelovalo 58 različnih genotipov oljne in krmne ogrščice, od tega je bilo 28 vpisanih v Sortno listo v posameznem letu. Povprečni pridelki oljne ogrščice se gibljejo med 1,8 in $2,9 \mathrm{t} / \mathrm{ha}$. $\mathrm{V}$ slovenskih razmerah razdrobljene posestne strukture obstajajo možnost oprašitve posevkov $B$. napus s samosevnimi in podivjanimi populacijami (znotraj in zunaj pridelovalnih površin). Poleg tega se v pri nas pojavljajo nekateri spolno kompatibilni sorodniki, ki imajo visoko sposobnost oprašitve $\mathrm{z} B$. napus (B. rapa, B. oleracea, $B$. nigra, Hirchfeldia incana, Raphanus raphanistrum, Sinapis arvensis, Diplotaxis erucoides, D. tenuifolia, D. muralis, S. alba, R. sativus and Rapistrum rugosum). Nenadzorovan prenos genov med različnimi pojavnimi oblikami B. napus ali spolno kompatibilnimi sorodniki v primeru soobstoja različnih sistemov pridelave neposredno vpliva na sortno čistost semenskih posevkov in na kvaliteto pridelka.

Ključne besede: Brassica napus L., oljna ogrščica, obseg pridelave, sortna struktura, divji sorodniki, samosevci, podivjane populacije, prenos genov

\footnotetext{
1 Res. Assist., B. Sc., Crop and Seed Science Department; Agricultural Institute of Slovenia, Hacquetova 17, SI-1001 Ljubljana; E-mail: barbara.pipan@kis.si

2 Assist. Prof. Ph. D., Crop and Seed Science Department; Agricultural Institute of Slovenia, Hacquetova 17, SI-1001 Ljubljana

3 Assist. Prof. Ph. D., Crop and Seed Science Department; Agricultural Institute of Slovenia, Hacquetova 17, SI-1001 Ljubljana
} 


\section{INTRODUCTION}

Brassica napus L. is a widely cultivated plant species which belongs to the diverse cruciferous family (Brassicaceae). The species is divided into two subspecies groups. The first group includes swedes $(B$. napus ssp. napobrassica), the second one includes winter and spring B. napus ssp. napus forms which are used for oil production or fodder (Snowdon et. al., 2007). Fodder rape (B. napus L. ssp. napus) is grown as a fresh forage crop for livestock feeding or as an organic soil fertilizer for the incorporation of green biomass into the soil. Oilseed rape (B. napus L. ssp. napus, syn. oleifera) is predominantely used for oil production having high seed oil content. Good quality oilseed rape contains around $40 \%$ of oil and the meal contains around $45 \%$ of protein, mostly dependent on the environment, fertilization, agrotechnics and genotype (Lääniste et al., 2004). Oilseed rape is today the world's third-leading source of both, vegetable and oil extraction meal (Friedt and Snowdon, 2009).

Oilseed rape is the most important oil plant of temperate climate zone and a typical industrial plant. The oil is also used in more environmentally friendly and cost effective extraction technologies (biofuels, lubricants, surface coatings, polymers, medicinal). Meal proteins are used in bioplastics, adhesives, cosmetics, encapsulation agents, lawn care products and combustion material (IENICA, 2005).

In the Slovenian climatic conditions winter/biennial oilseed rape varieties (f. biennis) are grown (vernalization demands) while the production of spring, one year (f. annua) varieties is concentrated in warmer areas (Butruille et al., 1999). Winter B. napus is cultivated in most of Europe and Asia, whereas in Canada, northern Europe and Australia only spring forms are suitable (Snowdon et al., 2007).

The increased interest in production in recent years is the consequence of the new agricultural policies due to accession of Slovenia to the European Union (EU) in 2004. EU market conditions dictate useful incorporation of oilseed rape in conventional, integrated and organic farming. Multiple use of oilseed rape products throughout the world is possible due to the successful conventional breeding programmes in the past, which could be nowadays completed with the new methods of plant biotechnology (genetic engineering). Christen and Friedt (2007) proposed four major groups of traits in the
B. napus breeding programs: 1.) Agronomic traits include tolerance to late planting, winter hardiness, plant height and lodging resistance, early maturity, nutrient efficiency and drought tolerance, shattering resistance and herbicide tolerance. 2.) Disease and pest resistance are the following: Phoma and Vericillium, clubroot and Cylindorsporium, Sclerotinia, TuYV virus resistance and other insect and pest resistance. 3.) Yield potential traits include: oil content, seed yield components, harvest index, total and marketable seed yield. 4.) In addition to that, seed quality traits are also included: very low erucic acid content $(<0.2 \%)$, low glucosinolate content $(<18 \mathrm{mmol} / \mathrm{kg}$ seed $)$, reduced lignin content and improved digestibility (monogastric animals) (Christen and Friedt, 2007).

Oilseed rape is used primarily in industry for the biofuel production, varieties with low content of glucosinolates and erucic acid are used for the production of high quality vegetable oil, industrial residues are used for highly enriched protein livestock feed. Usefulness of raw oils is also widespread in lipochemistry (genotypes with high erucic acid) and phytopharmacy (genotypes with high levels of glucosinolates) (Eastham and Sweet, 2002). One of the very important environmental functions of $B$. napus production is in the time of full flowering, allowing pollinators and especially honey bees to forage and consequently boosting the honey production. From the environmental and economic perspective biofuel from oilseed rape is important as a renewable source of energy due to the continuous raise of the fossil fuel price and their unavailability in the future.

B. napus is also a very prospective crop in Slovenia. The aim of this paper is to expose the biological characteristics of $B$. napus that are important for the explanation of $B$. napus pollination relations and possibilities in the specific production conditions of Slovenia. The survey of production capacities and varietal structure of $B$. napus on the landscape and regional level are presented. The influence on the gene flow relations inside Brassicaceae family and coexistence of different cropping systems in fragmented $B$. napus small field production is discussed. Uncontrolled inter- and intra-specific hybridization of B. napus from different habitats in Slovenia may occur.

\section{B. NAPUS PRODUCTION DYNAMICS IN SLOVENIA}

In the period from 1984 to 1994 the organised production was led by one of the biggest oil factories in
Slovenia that introduced quality oilseed rape varieties to farmers, leading them throughout the entire production 
process and at the end purchasing their product. Due to the collapse of the entire production system and nationally unregulated market relationships, the oil factory did not renew the contracts with farmers for further oilseed rape production (Kocjan-Ačko, 1999). This was the reason why the production in 1995 decreased for $87 \%$ in comparison with the previous year (Figure 1). The period from 1995 to 2001 was the so called "dead period" because the oilseed rape production in Slovenia was minimal. The Slovenian market still felt the consequences of the end of the organized production lacking the possibility of selling the yield. Oilseed rape in that period disappeared from the Slovenian conventional crop rotation, but it was on the other hand still sown as a fodder crop or as a natural organic fertilizer for introduction of green biomass into the soil (Kocjan-Ačko, 1999).

The adaptation of the oilseed rape production requirements to the EU standards and demands, which started already in 2002, caused an increase in the production (Figure 1). Due to the introduction of direct payment from EU for the production of crops which are not used for food and feed and for the extension of crop rotation systems with new crops, oilseed rape became more and more interesting for farmers. Therefore, the area under oilseed rape was increasing until 2004 when Slovenia joined the EU. Such a dynamics continued and the production increased until 2007 (Figure 1) when it achieved $1.1 \%$ of all agricultural areas in Slovenia (SURS, 2011). The motivation of farmers to plant oilseed rape was strongly encouraged by direct payments, obligatory extension of crop rotation and reestablishement of contractual production by industry. In 2008 direct payments from the EU ceased causing certain decrease in the 2008 and 2009 production.

The oilseed rape yield [t/ha] varied between individual years due to different agro-climatic conditions for a specific year and variety planted. The yields in the period 1991 to 2009 ranged between $1.8 \mathrm{t} / \mathrm{ha}$ (2003) and $2.9 \mathrm{t} / \mathrm{ha}$ (1991) (Statistical Office of the Republic of Slovenia - SURS, 2011).

The total yield of oilseed rape for the entire Slovenia varied between individual years, dependent on yield and extends of production areas. The total yield ranged between $121 \mathrm{t}$ (1997) and $14740 \mathrm{t}$ (2007) (SURS, 2011).

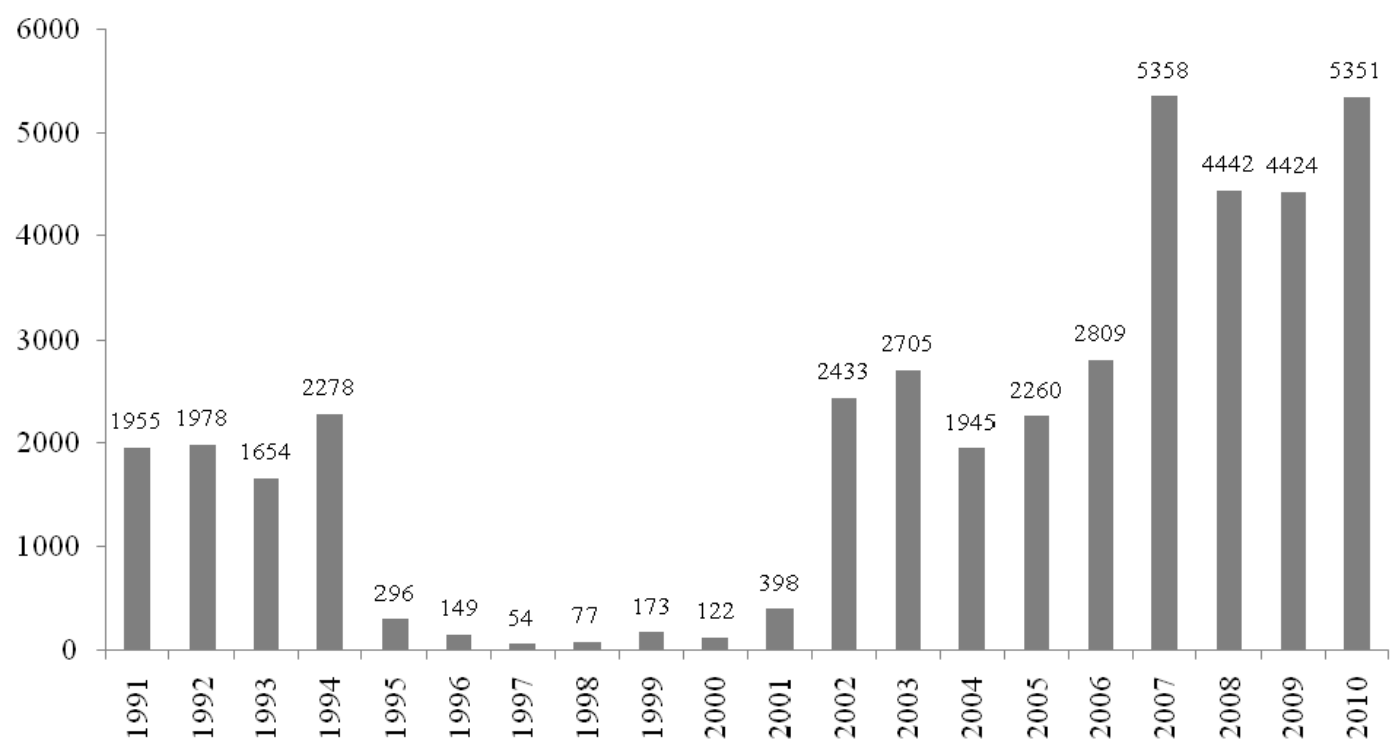

Figure 1: Oilseed rape production [ha] in Slovenia from 1991 to 2010 (SURS, 2011)

Slika 1: Pridelava oljne ogrščice [ha] v Sloveniji od 1991 do 2010 (SURS, 2011)

Oilseed rape production on the regional level

Oilseed rape production is concentrated to the east cohesive region of Slovenia. The data about its production from 2007 to 2009 are presented in Table 1 (SURS, 2011). 
Table 1: Oilseed rape production [ha] for cohesive regions of Slovenia (data for 2010 are not yet available) (SURS, 2011)

Preglednica 1: Pridelava oljne ogrščice [ha] po kohezijskih regijah v Sloveniji (podatki za 2010 še niso na voljo) (SURS, 2011)

\begin{tabular}{|c|c|c|c|c|c|c|}
\hline & 2007 & & 2008 & & 2009 & \\
\hline & $\begin{array}{l}\text { East } \\
\text { Slovenia }\end{array}$ & $\begin{array}{l}\text { West } \\
\text { Slovenia }\end{array}$ & $\begin{array}{l}\text { East } \\
\text { Slovenia }\end{array}$ & $\begin{array}{l}\text { West } \\
\text { Slovenia }\end{array}$ & $\begin{array}{l}\text { East } \\
\text { Slovenia }\end{array}$ & $\begin{array}{l}\text { West } \\
\text { Slovenia }\end{array}$ \\
\hline $\begin{array}{l}\text { Oilseed rape } \\
\text { production } \\
\text { [ha] }\end{array}$ & 5235 & 123 & 4281 & 161 & 4293 & 131 \\
\hline
\end{tabular}

Slovenian agricultural production areas are represented by 12 statistical regions. The oilseed rape production on the regional level is presented in Table 2 . The data are available only from 2007 to 2009 . Difference in the total oilseed rape production from SURS in 2009 (4424 ha) and summarized data from GERK (Land Parcel Information System - LPIS) evidence (2503.69) data between areas is derived from different sources and methods of raw data collection (difference between orto-photo pictures and the actual situation on particular field; B. napus sown as a main crop in the cropping system, where B. napus as a fodder rape is not included; all fields (farms) are not contained in the GERK evidence).

Table 2: $\quad$ Oilseed rape production in twelve statistical regions in Slovenia in 2009 (source: GERK evidence by Ministry of Agriculture, Forestry and Food)

Preglednica 2: Pridelava oljne ogrščice v dvanajstih statističnih regijah v Sloveniji v 2009 (podatki izvirajo iz GERK evidence na Ministrstvu za kmetijstvo, gozdarstvo in prehrano)

\begin{tabular}{|c|c|c|c|}
\hline Statistical regions & $\begin{array}{l}\text { Oilseed rape } \\
\text { production area }\end{array}$ & $\begin{array}{l}\text { \% of regional } \\
\text { oilseed rape }\end{array}$ & $\begin{array}{l}\text { Average size of fields } \\
\text { with oilseed rape [ha] }\end{array}$ \\
\hline 01 Pom urska & 1205.18 & 48.14 & 0.90 \\
\hline 02 Podravska & 910.06 & 36.35 & 2.72 \\
\hline 03 Koroška & 2.6 & 0.10 & 0.43 \\
\hline $04 \mathrm{~S}$ avinjska & 68.27 & 2.73 & 1.90 \\
\hline $05 \mathrm{Z}$ asavska & 0 & 0 & 0 \\
\hline 06 Spodnj e-posavska & 200.59 & 8.01 & 0.98 \\
\hline 07 Jugovzhodna Slovenia & 20.22 & 0.81 & 2.53 \\
\hline 08 O sredn jeslovenska & 56.76 & 2.27 & 2.27 \\
\hline 09 Gorenjska & 37.01 & 1.48 & 3.36 \\
\hline 10 Notranjjko-kraška & 0.28 & 0.01 & 0.28 \\
\hline 11 Goriška & 0.56 & 0.02 & 0.28 \\
\hline 120 ba ln o-k raška & 0 & 0 & 0 \\
\hline $00 \mathrm{Non}-\mathrm{d}$ ef in ing areas & 2.16 & 0.09 & 0.43 \\
\hline Total & 2503.69 & - & - \\
\hline Average & - & - & 1.46 \\
\hline
\end{tabular}

The oilseed rape production is most extensive in the Pomurska and Podravska region where geographic and agro-climatic conditions are widely suitable. Fragmental landscape reflected in the field size of production areas; 
average field size on the regional level is only 1.46 ha. Graphical presentation of oilseed rape production at the

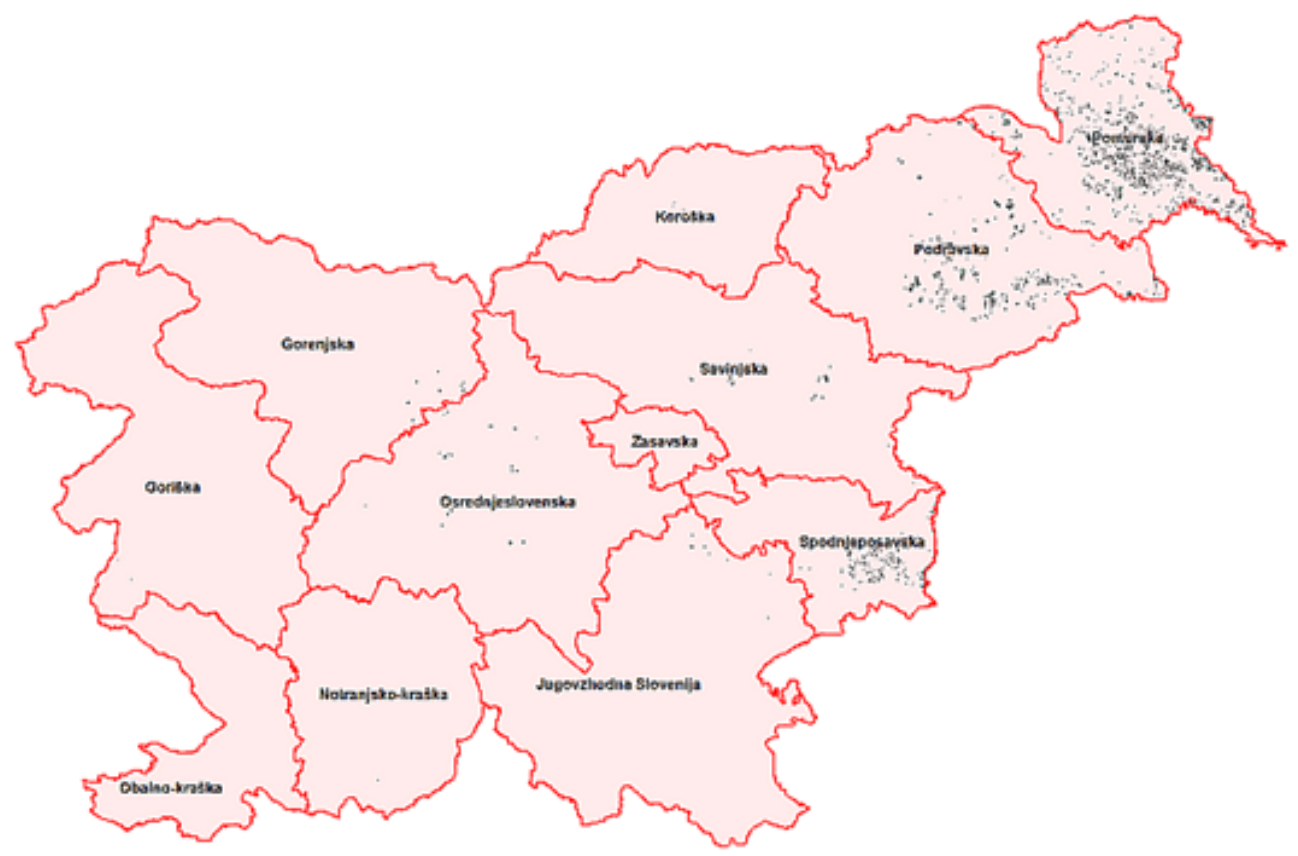

Figure 2: Graphical presentation of oilseed rape production in 12 statistical regions in Slovenia in 2009 (modelling and cartography: Jani Bergant, Agricultural Institute of Slovenia; data from the GERK evidence by Ministry of Agriculture, Forestry and Food; map: Ministry of the Environment and Spatial Planning)

Slika 2: Grafična predstavitev pridelave oljne ogrščice v 12ih statističnih regijah Slovenije v 2009 (oblikovanje in cartografija: Jani Bergant, Kmetijski inštitut Slovenije, podatki izvirajo iz GERK evidence na Ministrstvu za kmetijstvo, gozdarstvo in prehrano; podlaga: Ministrstvo za okolje in prostor).

\section{VARIETAL STRUCTURE OF B. napus}

The overall data about cultivated varieties in the Slovenian production area in the past was collected through official publications (National List of Varieties -NLV) and internal sources (market catalogues from different seed companies in Slovenia, results from variety tests and other internal registers held at Agricultural Institute of Slovenia).

In the period between 1984 and 1994 when the B. napus production in Slovenia was organised, farmers grew varieties with higher yields and lower levels of antinutritive substances (erucic acid, glucosinolates) for food and feed. These varieties were the following: the French variety 'Jet neuf', two German varieties, 'Darmor' and 'Tandem', later on the French variety 'Bienvenu' and the two Croatian varieties, 'Danica' and 'Zora', and also the variety 'Gorczanski' or the synonym 'Brilland' (Kocjan-Ačko, 1999). These varieties were also grown until 2000 (Ambrožič-Turk et.al., 1997; Ileršič, 1999; Ileršič and Rogelj, 2000); the first NLV was published in 1997 (Ambrožič-Turk et.al., 1997). In 2001, 'Darmor', 'Tandem', 'Bienvenu', 'Danica', 'Zora' and 'Gorczanski' were inscribed in the NLV (Bogolin et al., 2001). Only varieties 'Darmor', 'Bienvenu', 'Danica', 'Zora' and 'Gorczanski' were registered in the NLV in 2002 (Bogolin et al., 2002). The result of the national $B$. napus breeding programme was the fodder variety 'Starška' released in 1989. In 2003, NLV was not published due to the revision of the previous NLV and adaptation to the new seed legislation. 
Barbara PIPAN in sod.

Table 3: The B. napus varieties and hybrids in the NLV from 2004 to 2010 ( $\bullet$ registered or $\circ$ unregistered in each year)

Preglednica 3: Sorte in hibridi B. napus, vpisani v Sortno listo od 2004 do $2010(\bullet$ registrirana ali $\circ$ neregistrirana v posameznem letu)

\begin{tabular}{|c|c|c|c|c|c|c|c|}
\hline $\begin{array}{l}\text { Varieties of } \\
\text { B. napus }\end{array}$ & $\begin{array}{l}2004 \\
\text { (Bogolin } \\
\text { et al., } \\
2004 \text { ) } \\
\end{array}$ & $\begin{array}{l}2005 \\
\text { (Bogolin } \\
\text { et al., } \\
2005 \text { ) } \\
\end{array}$ & $\begin{array}{l}2006 \\
\text { (Ileršič et } \\
\text { al., 2006) }\end{array}$ & $\begin{array}{l}2007 \\
\text { (Ileršič et } \\
\text { al., 2007) }\end{array}$ & $\begin{array}{l}2008 \\
\text { (Grižon } \\
\text { et al., } \\
2008) \\
\end{array}$ & $\begin{array}{l}2009 \\
\text { (Rakovec } \\
\text { et al., } \\
2009 \text { ) } \\
\end{array}$ & $\begin{array}{l}2010 \\
\text { (Rakovec } \\
\text { et al., } \\
2010) \\
\end{array}$ \\
\hline 'Adder' & 0 & $\bullet$ & • & 0 & 0 & 0 & 0 \\
\hline 'Akela' & $\bullet$ & o & o & O & o & O & O \\
\hline 'Alaska' & 0 & $\bullet$ & $\bullet$ & 0 & 0 & 0 & 0 \\
\hline 'Allure' & O & $\bullet$ & - & O & O & o & O \\
\hline 'Arista' & - & 0 & 0 & 0 & 0 & 0 & 0 \\
\hline 'Bienvenu' & $\bullet$ & 0 & 0 & 0 & 0 & 0 & 0 \\
\hline $\begin{array}{l}\text { 'Brilland'/' } \\
\text { Gorczanski }\end{array}$ & $\bullet$ & 0 & O & o & o & O & O \\
\hline 'Bristol' & 0 & $\bullet$ & $\bullet$ & $\bullet$ & $\bullet$ & $\bullet$ & o \\
\hline 'Danica' & - & 0 & 0 & 0 & 0 & 0 & 0 \\
\hline 'Daniela' & o & - & - & - & $\bullet$ & - & - \\
\hline 'Darmor' & - & 0 & O & 0 & 0 & 0 & O \\
\hline 'Digger' & O & $\bullet$ & $\bullet$ & O & O & 0 & O \\
\hline 'Gabriella' & O & $\bullet$ & $\bullet$ & - & $\bullet$ & 0 & O \\
\hline $\begin{array}{l}\text { 'GK } \\
\text { Helena' }\end{array}$ & o & $\bullet$ & $\bullet$ & o & o & o & o \\
\hline 'Helga' & 0 & 0 & • & - & - & - & - \\
\hline 'Milena' & 0 & - & $\bullet$ & O & o & O & O \\
\hline 'Petranova' & - & 0 & 0 & 0 & 0 & 0 & 0 \\
\hline 'PR45D01' & O & O & O & O & O & o & - \\
\hline 'PR45D03' & O & O & O & 0 & O & o & - \\
\hline 'PR45W04' & 0 & $\bullet$ & $\bullet$ & $\bullet$ & $\bullet$ & $\bullet$ & $\bullet$ \\
\hline 'PR46W14' & O & O & O & 0 & o & O & $\bullet$ \\
\hline 'PR46W15' & O & o & o & o & o & 0 & $\bullet$ \\
\hline 'PR46W31' & 0 & $\bullet$ & $\bullet$ & $\bullet$ & $\bullet$ & $\bullet$ & $\bullet$ \\
\hline 'Starška' & - & o & $\bullet$ & $\bullet$ & - & $\bullet$ & - \\
\hline 'Titan' & 0 & 0 & 0 & $\bullet$ & $\bullet$ & $\bullet$ & $\bullet$ \\
\hline 'Viking' & o & o & O & $\bullet$ & $\bullet$ & 0 & o \\
\hline 'Zenith' & O & $\bullet$ & $\bullet$ & 0 & O & 0 & O \\
\hline 'Zora' & $\bullet$ & 0 & 0 & 0 & 0 & 0 & 0 \\
\hline
\end{tabular}

Along with the B. napus varieties registered in the Slovenian NLV, other commercially important varieties have been and still are cultivated and are inscribed in the Common Catalogue of Varieties of Agricultural Plant Species. From 1984 to 2010 a total of 58 different varieties for food and feed were grown in Slovenia. These varieties were produced as oil varieties (for oil industry) and as spring varieties for animal feed as fresh fodder. The list of all varieties grown in Slovenia and their use is presented in Table 4. 
Table 4: Varietal structure of B. napus in Slovenia from 1984 to 2010 and forms/type of use (Pipan et. al., 2010; Hasan et. al., 2006); W-winter form, S-spring form, OSR-oilseed rape, F-fodder rape

Preglednica 4: Sortna struktura B. napus v Sloveniji od 1984 do 2010 in oblike/tipi uporabe (Pipan et. al., 2010; Hasan et. al., 2006); W-ozimna oblika, S-jara oblika, OSR-oljna ogrščica, F-krmna ogrščica

\begin{tabular}{ll|ll}
\hline Na me of variety/hybrid & Form/type of usage & Name of variety/hybrid & Form/type of usage \\
\hline 'Adder' & WOSR & 'Petrol' & WOSR \\
\hline 'Akela' & WF & 'PR44W29' & WOSR \\
'Alaska' & WOSR & 'PR45D01' & WOSR \\
'Allure' & WOSR & 'PR45D03' & WOSR \\
'Arista' & SF & 'PR45D05' & WOSR \\
'Baldur' & WOSR & 'PR45W04' & WOSR \\
'Baros' & WOSR & 'PR46W14' & WOSR \\
'Bienvenu' & WOSR & 'PR46W15' & WOSR \\
'Brilland'='Gorczanski & WOSR & 'PR46W24' & WOSR \\
'Bristol' & WOSR & 'PR46W31' & WOSR \\
'Danica' & WOSR & 'Rasmus' & WOSR \\
'Daniela' & WF & 'Remy' & WOSR \\
'Darmor' & WOSR & 'Robust' & WOSR \\
'Digger' & WF & 'Rodeo' & WOSR \\
'Express' & WOSR & 'Rohan' & WOSR \\
'Gabriella' & WOSR & 'Smart' & WOSR \\
'GK Helena' & 'Starška' & WF \\
'Helga' & WOSR & 'Tandem' & WOSR \\
'Honk' & SF & 'Tassilo' & WOSR \\
'Jet Neuf' & WOSR & 'Titan' & WOSR \\
'Kronos' & WOSR & 'Triangle' & WOSR \\
'Milena' & WOSR & 'Viking' & WOSR \\
'Mohican' & WF & 'Visby' & WOSR \\
'Molino' & WOSR & 'Viva' & WF \\
'Navajo' & WOSR & 'X08W982 I.' & WOSR \\
'NK Nemax' & 'X08W984 I.' & WOSR \\
'NS-L-36' & 'Xenon' & WOSR \\
'NS-L-39' & WOSR & 'Zenith' & WOSR \\
'Ontario' & WOSR & WOSR \\
'Petranova' & WOSR & WOSR \\
\hline & SF & & \\
\hline & & Bikovo & \\
\hline
\end{tabular}

\section{THE SIGNIFICANCE OF GENE FLOW OF B. napus}

Gene flow through pollen transfer between different appeared forms of $B$. napus and its sexually compatible relatives which are mostly found as weedy plants has biological, genetic, economical and ecological consequences. An important breakpoint in the farming process was the adoption of national legislation and regulation on co-existence of different cropping systems in the Slovenian production area in 2009 when Slovenia adopted the Act on Co-existence of Genetically
Modified Plants with Other Agricultural Plants (Uradni list, 2009).

\section{Genetic origin of $B$. napus}

B. napus originated through spontaneous inter-specific hybridisation (followed by polyploidisation) between turnip rape (B. rapa L.; genome $\mathrm{AA}, 2 \mathrm{n}=20$ ) and cabbage (B. oleracea $\mathrm{L}$.; genome $\mathrm{CC}, 2 \mathrm{n}=18$ ), resulting in alotetraploid genome comprising the full 
chromosome complements of its two progenitors (Friedt and Snowdon, 2009). Song and Osborn (1992) suggest that $B$. montana $(2 n=18)$ might be closely related to the prototype derived to both cytoplasms of $B$. rapa and $B$. oleracea through analyses of mitochondrial and chloroplast DNA.

The origin of B. napus is also described by Triangle of U (Nagaharu, 1935). This theory explains the evolution and the relationships between six oil and vegetable species from the Brassica genus. It is about the combination of three genomes from the genus Brassica (B. nigra, B. oleracea, B. rapa) which are ancestral to other three inter-specific hybrids (B. carinata, $B$. juncea, B. napus) (Figure 3).

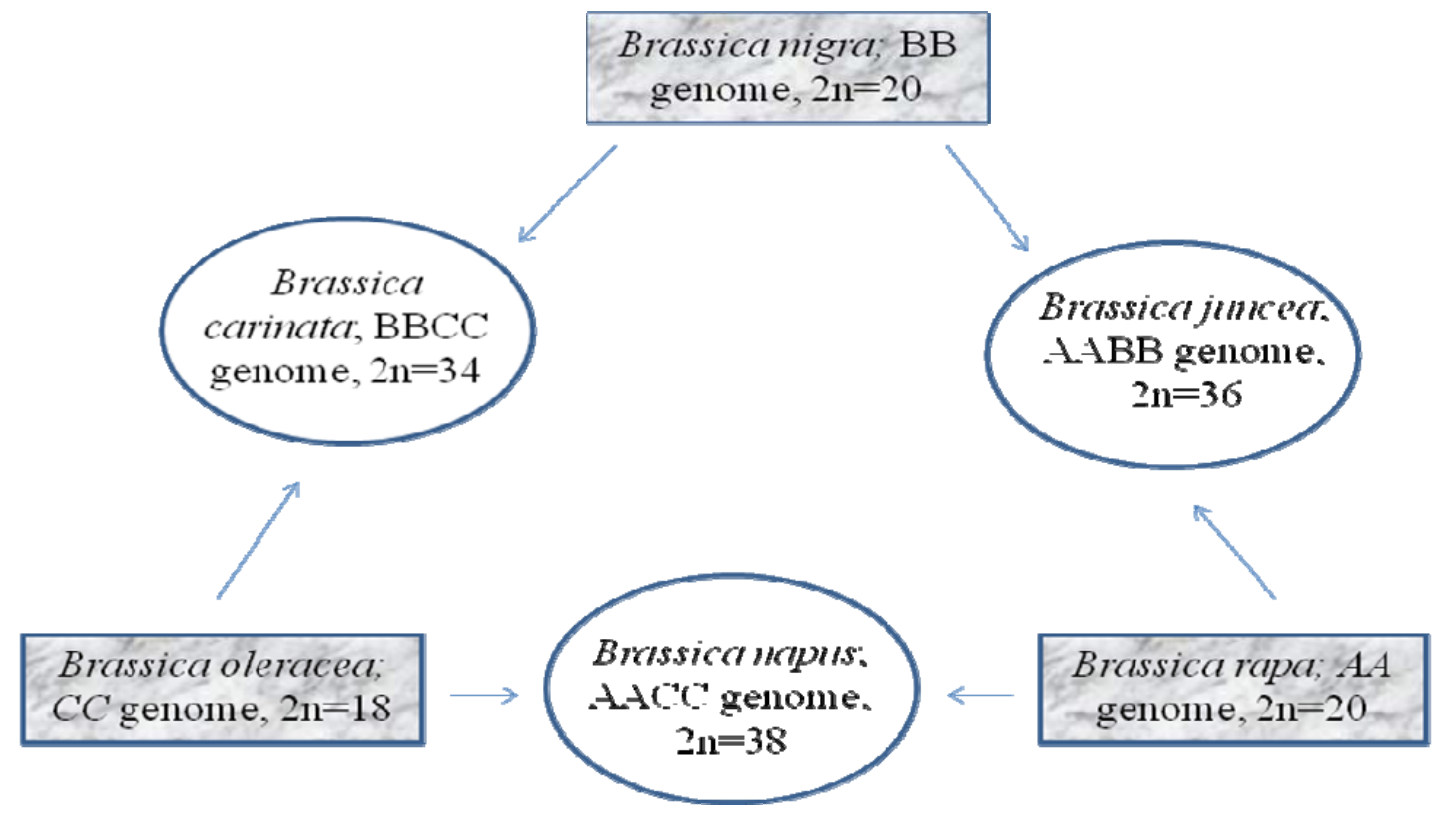

Figure 3: Triangle of U-diagram (Nagaharu, 1935)

Slika 3: Trikotni U-diagram (Nagaharu, 1935)

It is considered that $B$. napus is a relatively young species originated only a few centuries ago. Spontaneous hybridization between $B$. rapa and $B$. oleracea (from Europe and Asia) occurred by contemporary cultivation of both species in a small geographic area of the Mediterranean region (Friedt and Snowdon, 2009).

B. napus is a self fertile and mainly autogamous species with variable degree of cross-pollination. Treu and Emberlin (2000) reported on 5-30\% cross-pollination level under field conditions and about $41 \%$ out-crossing with the amount differing in relation to the prevailing environmental conditions. its pollen could be dispersed mainly by insects and to a smaller amount also by wind. Both are probably affected by location, weather and plant genotype. The pollen grains are fairly large (32$33 \mu \mathrm{m})$, heavy, sticky and consequently typical for insect pollination (Simpson et al. 1999; Treu and Emberlin, 2000).
There is no evidence that $B$. napus does exist as a wild plant but it frequently appears as a feral plant outside the cultivation areas. There are a few traits which are typical for wild plants and are also presented in $B$. napus (easy dehiscence of its pods, secondary dormancy of the seeds, annually adapted seed germination) (Pascher et al., 2010).

\section{Possibilities for cross-pollination with B. napus}

Pollen dispersal and gene flow between $B$. napus and other sexually compatible plants is possible due to its variable cross-pollination level. In the Slovenian production area $B$. napus from various habitats (cultivated, volunteers, feral populations) and some compatible relatives from Brassicaceae family could be found.

\section{Intra-specific hybridization}

Intra-specific hybridization is possible among B. napus in field conditions and between different plant forms 
from various (semi) natural habitats. Pollination relations occur between cultivated B. napus (mainly oilseed rape varieties), volunteers (grown from seed losses in previous years inside cultivated areas) and ferals (grown from the soil seed bank outside cultivation areas, mainly along the transportation infrastructure) (Pascher et al., 2006, Pipan et al., 2008). In the case of coexistence of different farming systems which includes genetically modified (GM) oilseed rape production, introduction of transgenes in B. napus or related species is possible (Pascher et al., 2010).

Volunteers within cultivation areas originated from seed losses due to the natural shedding and crop disturbance during harvest (inappropriate additional equipment of combine harvesters). Because of unsuitable agrotechnical procedures, the lost seeds are accumulated in the soil seed bank and appear when conditions for germination are optimal. Consequently, B. napus appears as a volunteer and as a weed in other crops cultivated in the same production areas in the following years (Price et al., 1996). Lutman (1993) reported that seed losses in adverse conditions can exceed $20 \%$ of the yield.

The presence of volunteers in Slovenia is concentrated in regions where oilseed rape production is widely extended. The problematic zones within cultivated areas are field margins that are very often not included in cultivation and fields where oilseed rape production is not intensive (leaving off farming) (Pipan et al., 2010).

Feral B. napus populations appear outside cultivation areas. Their persistence is typical for pioneer habitats like tracks, roadsides, waste sides, rubble tips, and riverbanks (Privard et al., 2008). The origin of feral B. napus populations results from the soil seed banks around transportation infrastructure. The seeds are viably persistent in the soil for at least eight years. Soil seed bank enrichment is mainly possible continually via seed spillage from trucks in transit over the country (Crawley, 2004; Pessel, 2001).

The presence of volunteer and feral B. napus populations in oilseed rape production areas can cause problems for varietal purity and yield quality. Food and feed products could consequently contain higher levels of anti-nutritional substances. Coexistence of GM and non-GM oilseed rape production could cause the uncontrolled transfer of transegnes into cultivated nonGM B. napus or to other sexually compatible plants (Claessen et al., 2005). The ecological aspect of described relations has an important impact on B. napus gene pool and sustainable food and feed production. The persistence of feral B. napus population in Slovenia was observed allong all types of roads and in other ruderal habitats (embankments, heaps) (Pipan et al., 2010).

B. napus is a model species of particular interest for assessing risks of transgene escape from cultivated fields. Modeling approaches have been shown as essential since they allow exploration of a wide range of input values. Begg et al., (2006) has developed a model on the persistence of existing transgenic event introduced into oilseed rape which explores the effects of demographic and agronomic factors under the influence of spatial processes. Colbach et al. (2001a and 2001b) developed the so-called GENESYS model in which they established how the agricultural practice influenced the gene flow from GM oilseed rape (it possesses an inserted gene for the resistance to herbicide) to volunteers in the following years of production.

\section{Inter-specific hybridization}

Inter-specific hybridization between $B$. napus is possible with some sexually compatible plants from Brassicaceae. The relatives of $B$. napus are cultivated as crops and others that are known as weeds in farming systems and wild flowers outside cultivated areas (Estham and Sweet, 2002). There are many species closely related to $B$. napus such as: $B$. rapa, $B$. juncea, B. oleracea, B. nigra, Hirchfeldia incana, Raphanus raphanistrum, Sinapis arvensis, Diplotaxis erucoides, $D$. tenuifolia, D. muralis, S. alba, R. sativus and Rapistrum rugosum. (Estham and Sweet, 2002; Pascher et al. 2010; Treu and Emberlin, 2000). These plants could be found inside and outside the cultivated areas (field edges, shelterbelts, road verges, slag heaps, embankments, etc) (Pascher et al., 2010). Scheffler and Dale (1994a) report that the opportunity for interspecific hybridization is dependent on: physical distance between two species, synchrony of flowering, method of pollen dissemination, parental genotype characteristics and environmental conditions. The highest pollination affinity to $B$. napus has especially $B$. rapa and also $B$. oleracea and $B$. juncea. The hybrids which were obtained between $B$. napus and the wild relative are not always viable. The success of its existence is influenced by: fertility, ability to propagate vegetatively, ability to give viable F2 generation (Scheffler and Dale, 1994a). Successful spontaneous hybridizations (without emasculation or manual pollination) between B. napus and B. rapa, B. juncea, $B$. nigra, $H$. incana, $R$. raphanistrum have been documented and all of the F2 hybrids and backcross progeny was produced (Scheffler and Dale, 1994b).

Sagers et al. (2010) have recently reported about the problem of uncontrolled gene flow, which describes the presence of the transgene (for herbicide tolerance) in 
feral populations of $B$. napus among transportation infrastructure in North Dakota. The report especially exposed a high probability of gene transfer between sexually-compatible relatives of $B$. napus outside production areas and global implications of such activities for farmers, consumers and for the environment.

There are some closely related Brassicaceae species, which are also represented in the Slovenian production area. According to Jogan (2001) different species are spread around the country: B. rapa, B. oleracea, $B$. nigra, Raphanus raphanistrum, $R$. sativus, Diplotaxis muralis, D. tenuifolia, Sinapis alba, S. arvensis and Rapistrum rugosum. They could be cultivated (S. alba, B. rapa, B. oleracea), weedy or wild.

\section{Pollen dispersal characteristics of $B$. napus}

The biennial B. napus is grown in Slovenia because of overwintering vernalization demands. It flowers in April to early May, the annual (spring) B. napus which is sown and harvested in the same year, flowers one month later than winter forms. Consequently, it is widely believed that the insects have more important role in the cross-pollination of later flowering crops (Estham and Sweet, 2002). Ramsay et al., (1999) reported that bees from the same hive could transfer pollen from 2 up to 4 $\mathrm{km}$ in all directions. The theoretically expected pollen transfer by insects is up to $10 \mathrm{~km}$, but the distances are influenced by environmental and topographical conditions. The pollen viability under in vitro conditions is between 24 hours and 7 days (Mesquida and Renard, 1982) and under natural conditions from 4 up to 5 days (Ranito-Lehtimäki, 1995). B. napus is a facultative outcrossing species; in presence of insect pollinators (Apis mellifera, Bombus sp.) higher proportion of crosspollination could occur (Snowdon et al., 2007). B. napus pollen ( $8-40 \%$ of proteins) is also highly nutritive for bees (Estham and Sweet, 2002).

Inside cultivation areas the usual level of crosspollination is from 20 to $30 \%$ (Squire et al., 2003). The level of cross-pollination between different varieties with full fertility is up to $0.1 \%$ on the field-to-field scale, while in varieties with incorporated male sterility (bait plants; they produce no pollen on their own and represent the 'worst case scenario' on the crosspollination level) it is higher than $1 \%$ (Squire et al, 2003). Cross-pollination is most prominent on field margins and starts diminishing after $10 \mathrm{~m}$, but, in spite of that, the pollination at greater distances is not excluded. This is more frequent in cases when in the surrounding of donor plant/cultivated crop no other flowering plants are present. The rate of crosspollination is significantly influenced by proportions between donor and recipient plants (Squire et al., 2003).

Cleistogamy of $B$. napus is a trait of non-opening flowers which could be used to reduce pollen dispersal and it could be beneficially used in combination with other means in a gene flow control strategy. The problem of cleistogamous $B$. napus genotypes is their stability under field conditions because cleistogamous plants do not exist naturally among $B$. napus gene pool (Leflon et al., 2010).

Fragmented landscape and small-sized oilseed rape fields in Slovenia is very heterogeneous. Because of different ecological barriers like landscape structural elements (small woods, hedges, overgrown paths and hills), the pollen transfer by insects and wind to long distances is disturbed. There is no specific pattern of pollen dispersal and out-crossing on short distances (neighboring fields, weedy relatives, ferals, and volunteers) is favorable.

\section{CONCLUSION}

Heterogeneous growing conditions are reflected in the fragmental landscape production on the regional level and small sized fields. In Slovenia, the production of $B$. napus is mostly concentrated in the Pomurska and Podravska region (East Slovenia), where the average field size at the regional level is 1.46 ha.

Diverse list of varieties and hybrids, which are (were) grown in Slovenia is mostly the consequence of agropolitical regulations at EU level. As type and form of $B$. napus, mostly the winter oilseed rape is produced in Slovenia. The GM B. napus is not yet grown in the EU although national legislations on co-existence of genetically modified plants with other agricultural plants are generally in place; in Slovenia it has been regulated since 2009 .

Knowledge about all B. napus forms (cultivated, volunteer plants, feral populations) and their relevance in hybridization relations brings important basic information for survey studies of naturally occurred genetic diversity of $B$. napus on the national level. Consequently, it is important to assess reasons, solutions and problems related with persistence of volunteers and ferals which directly and indirectly influence food and feed production. In case of the genetically modified $B$. napus cultivation, there is a possibility of introduction of transgenes to non-GM 
relatives due to the persistence from cultivation or transport spillage. Growing conditions and production in different cropping systems dictate consistent and intensive B. napus (mostly oilseed rape) production which should be economically and environmentally friendly. Choosing right solutions will significantly influence the yield quality or seed purity in sustainable food and feed production and could have impact on the agro-biodiversity.

\section{REFERENCES}

Ambrožič-Turk, B., Čergan, Z., Černe, M., Dolničar, P., Ileršič, J., Koruza, B., Pečnik, M., Spanring J., Ugrinović, K., Verbič, J., Zemljič, A. (1997): National List of Varieties. Phytosanitary Administration of the Republic of Slovenia, Ljubljana: 121p.

Begg, G.S., Hockaday, S., McNicol, J.W., Askew, M., Squire, G.R. (2006): Modelling the persistence of volunteer oilseed rape (Brassica napus L.). Ecol Model., 198: 195-207.

Bogolin, M., Ileršič, J., Koruza, J. (2001): National List of Varieties. Phytosanitary Administration of the Republic of Slovenia, Ljubljana: 78 p.

Bogolin, M., Ileršič, J., Pečnik, M., Rakovec, H., RogeljZupan, M. (2004): National List of Varieties. Phytosanitary Administration of the Republic of Slovenia, Ljubljana: $69 \mathrm{p}$.

Bogolin, M., Ileršič, J., Pečnik, M., Rogelj-Zupan, M. (2005): National List of Varieties. Phytosanitary Administration of the Republic of Slovenia, Ljubljana: $20 \mathrm{p}$.

Bogolin, M., Rogelj-Zupan, M., Ileršič, J. (2002): National List of Varieties. Phytosanitary Administration of the Republic of Slovenia, Ljubljana: $90 \mathrm{p}$.

Butruille, D.V., Guries, R.P., Osborn, T.C. (1999): Linkage analysis of molecular markers and quantitative trait loci in populations of inbred backcross lines of Brassica napus L. Genetics, 153: 949-964.

Christen, O., Friedt, W. (2007): Winterraps: Das Handbuch für Profis. DLG- Verlag, Frankfurt: $323 p$.

Claessen, D., Gilligan, C.A., Lutman, P.J.W., van den Bosch, F. (2005): Which traits promote persistence of feral GMO plants? Part 1: implications of environmental stochasticity. Oikos, 110: 20-29.

Colbach, N., Clermont-Dauphin, C., Meynard, J.M. (2001a): GENESYS: a model of the influence of cropping system on gene escape from herbicide tolerant rapeseed crops to rape volunteers. II. Genetic exchanges among volunteer and cropped populations in a small region. Agriculture, Ecosystems and Enironment, 83: 255-270.

Colbach, N., Clermont-Dauphin, C., Meynard, J.M. (2001b): GENESYS: a model of the influence of cropping system on gene escape from herbicide tolerant rapeseed crops to rape volunteers. I. Temporal evolution of a population of rapeseed volunteers in a field. Agriculture, Ecosystems and Enironment, 83: 235-253.
Crawley, M.J., Brown, S.L. (2004): Spatially structured population dynamics in feral oilseed rape. Proc. R. Soc. B., 271: 1909-1916.

Eastham, K., Sweet, J. (2002): Genetically modified organisms (GMOs): The significance of gene flow through pollen transfer. Environmental issue report, 28: 15-26.

Friedt, W., Snowdon, R. (2009): Oilseed rape. In: Oil Crops, Handbook of Plant Breeding 4. Vollman, J., Rajcan, I. (eds.).Giessen, Springer Science+Business Media: 91126.

Grižon P., Ileršič, J., Pečnik, M., Rakovec, H. (2008): National List of Varieties. Phytosanitary Administration of the Republic of Slovenia, Ljubljana: $22 p$.

Hasan, M., Seyis, F., Badani, A.G., Pons-Kühnemann, J., Friedt, W., Lühs, W., Snowdon, R.J. (2006): Analysis of genetic diversity in the Brassica napus L. gene pool using SSR markers. Genetic Resources and Crop Evolution, 53: 793-802

IENICA. (2011): www.ienica.net/reports/ienicafinalsummary report2000-2005.pdf, 19.1.2011.

Ileršič, J. (1999): National List of Varieties. Phytosanitary Administration of the Republic of Slovenia, Ljubljana: $104 p$.

Ileršič, J., Pečnik, M., Rogelj-Zupan, M. (2007): National List of Varieties. Phytosanitary Administration of the Republic of Slovenia, Ljubljana: 20 p.

Ileršič, J., Pečnik, M., Rogelj-Zupan, M., Grižon P. (2006): National List of Varieties. Phytosanitary Administration of the Republic of Slovenia, Ljubljana: $21 p$.

Ileršič, J., Rogelj, M. (2000): National List of Varieties. Phytosanitary Administration of the Republic of Slovenia, Ljubljana: $79 p$.

Jogan, N. (2001): Materials for the Atlas of Flora of Slovenia. Miklavž na Dravskem polju, Trajanus: $443 p$.

Kocjan-Ačko, D. (1999): Pozabljene poljščine. Založba kmečki glas, Ljubljana, 187 p.

Lääniste, P., Jõudu, J., Eremeev V. (2004): Oil content of spring oilseed rape seeds according to fertilization. Agronomy research, 2: 83-86.

Leflon, M., Hüsken, A., Njontie, C., Kightley, S., Pendergrast, D., Pierre J., Renard M., Pinochet, X. (2010): Stability of the cleistogamous trait during the flowering period of oilseed rape. Plant Breeding, 129: 13-18. 
Lutman, P. J. W. (1993): The occurrence and persistence of volunteer oilseed rape (Brassica napus). Aspects of Applied Biology, 35: 29-36.

Mesquida, J., Renard, M. (1982): Study of the pollen dispersal by wind and of the importance of wind pollination in rapeseed (Brassica napus var. oleifera Metzger). Apidologie, 4: 353-366.

Ministry of Agriculture, Forestry and Food. (10. 6. 2009): Internal GERK evidence (raw data).

Ministry of the Environment and Spatial Planning. (2.2.2011): Geographical grounding map.

Nagaharu, U. (1935): Genome analysis in Brassica with special reference to the experimental formation of $B$. napus and peculiar mode of fertilization. Japan J. Bot., 7: $389-452$.

Pascher, K., Macalka, S., Rau, D., Gollman, G., Reiner, H., Glössl, J., Grabherr, G. (2010): Molecular differentiation of commercial varieties and feral populations of oilseed rape (Brassica napus L.). BMC Evolutinary Bilogy, 10:63.

Pascher, K., Narendja, F., Rau, D. (2006): Feral Oilseed RapeInvestigations on its Potential Hybridisation. Final report in commission of the Federal Ministry of Health and Women, GZ 70420/0116-IV/B/12/2004: 56 p.

Pessel, F.D., Lecomte, J., Emeriau, V., Krouti, M., Messean, A., Gouyon, P.H. (2001): Persistence of oilseed rape (Brassica napus L.) outside of cultivated fields. Theor. Appl. Genet., 102: 841-846.

Pipan, B., Šuštar Vozlič, J., Meglič, V. (2008). Oilseed rape production at the Slovenian landscape level and survey of crop to wild gene flow. In: Implications of GM-crop cultivation at large spatial scales: Proceedings of the GMLS Conference 2008 in Bremen. Breckling, B., Reuter, H., Verhoeven, R. (eds.). Frankfurt: 27-29.

Pipan, B., Šuštar Vozlič, J., Meglič, V. (2010): Estimation of gene flow between oilseed rape populations from different habitats in Slovenia. In: New challenges in field crop production 2010: Proceedings of symposium, Kocjan Ačko, D., Čeh, B. (eds.). Ljubljana, Slovensko agronomsko društvo: 132-137.

Pivard, S., Adamczyk, K., Lecomte, J., Lavigne, C., Bouvier, A., Deville, A., Gouyon, P.H., Huet, S. (2008): Where do the feral oilseed populations came from? A largescale study of their possible origin in a farmland area. $J$. Appl. Ecol., 45: 476-485.

Price, J. S., Hobson, R. N., Neale, M. A., Bruce, D. M. (1996): Seed losses in commercial harvesting of oilseed rape. Journal of Agricultural Engineering, 65: 183-191.

Rakovec, H., Grižon, P., Pečnik, M., Ileršič, J. (2010): National List of Varieties. Phytosanitary
Administration of the Republic of Slovenia, Ljubljana: $23 \mathrm{p}$.

Rakovec, H., Pečnik, M., Grižon, P., Ileršič, J. (2009): National List of Varieties. Phytosanitary Administration of the Republic of Slovenia, Ljubljana: $25 \mathrm{p}$.

Ranito-Lehtimäki, A. (1995): Aerobiology of pollen and pollen antigens. In: Bioaerosols Handbook, Cox, C.S., Wathes, C.M. (eds.). Lewis publishers, Bedford: 387401.

Sagers, C.L., Schafer, M.G., Jaquish, B. 2010. Wild canola populations contain genes for herbicide tolerance. University of Arkansas, Arkansas Newswire (6.8.2010): http://newswire.uark.edu/article.aspx?id=14453.

Scheffler, J.A., Dale, P.J. (1994a): Opportunities for gene transfer from transgenic oilseed rape (Brassica napus L.) to related species. Transgenic Research, 3: 263-78.

Scheffler, J.A., Dale, P.J. (1994b): Opportunities for gene transfer and origin of crop Brassicas. Opera Bot., 55: 357.

Simpson, E. C., Norris, C. E., Law, J. R., Thomas, J. E., Sweet, J. B. (1999): Gene flow in genetically modified herbicide tolerant oilseed rape (Brassica napus) in the UK. In: Gene Flow and Agriculture: Relevance for Transgenic Crops. Lutman, P. (ed.). BCPC Symposium Proceedings No. 72, London: 286p.

Snowdon, R., Lühs, W., Friedt, W. (2007): Oilseeds. In: Genome Mapping and Molecular Breeding in Plants, Volume 2. Kole, C. (ed.). The Pennsylvania State University, Springer-Verlag Berlin Heidelberg: 55-114.

Song, K., Osborn, T.C. (1992): Polyphyletic origins of Brassica napus: new evidence based on organelle and nuclear RFLP analyses. Genome, 35: 992-1001.

Squire, G.R., Begg, G.S., Askew, M. (2003). The potential for oilseed rape feral (volunteer) weeds to cause impurities in later oilseed rape crops. Final report of the DEFRA project: Consequences for Agriculture of the Introduction of Geneticaly Modified Crops, RG0114.

SURS. (2011): http://www.stat.si/pxweb/Dialog/ Saveshow.asp, 18.1.2011.

Treu, R., Emberlin, J. (2000): Pollen dispersal of the crops Maize (Zea mays), Oilseed rape (Brassica napus), Potatoes (Solanum tuberosum), Sugar beet (Beta vulgaris) and Wheat (Triticum aestivum). A report for the Soil Association, University College, Bristol: 18-24.

Uradni list št. 41/2009: Act on Co-existence of Genetically Modified Plants with Other Agricultural Plants. 